\title{
Morphological variability of a root vole population in high mountain habitats, Hardangervidda, South Norway
}

\author{
Janusz MARKOWSKI and Eivind ØSTBYE
}

\begin{abstract}
Markowski J. and Østbye E. 1992. Morphological variability of a root vole population in high mountain habitats, Hardangervidda, South Norway. Acta theriol. 37: $117-139$.

The variability of body and skull dimensions was examined in a population of the root vole, Microtus oeconomus (Pallas, 1776) from high mountain habitats, Hardangervidda, southern Norway. Morphometric analysis was made on 530 of 915 specimens obtained over an 8 year trapping period $(1970-1978)$, taking into account sex, age class, season and population cycle. Sexual dimorphism was distinct in the oldest age group, in which males were significantly larger than females. The specimens from the peak phase were larger in body and skull dimensions (Chitty Effect). The influence of age structure on fluctuations in body size during the microtine cycles is discussed.

Department of Ecology and Vertebrate Zoology, University of Łodz, 90-237 Łódz, Banacha str. 12/16, Poland (JM); Department of Biology, Division of Zoology, University of Oslo, PO Box 1050, Blindern - Oslo 3, N-0316 Norway (EØ)
\end{abstract}

Key words: Microtus oeconomus, population cycle, Chitty Effect, body size, Norway

\section{Introduction}

The study of morphological variation in mammals is widely used in investigations on the structure and function of a species and analysis of its evolutionary transformations (Mayr 1963, Yablokov 1966, Schwarz 1969). Mammalogists are particularly interested in different morphological characteristics as related to cyclic fluctuating populations of microtines (Chitty 1952, Zimmermann 1955, Krebs 1964, Krebs and Myers 1974, Boonstra and Boag 1987).

Microtine species with cyclic populations have showed a relatively repeatable pattern of changes in body size, growth, age structure, age of sexual maturity and length of breeding season (see Krebs and Myers 1974, Krebs 1978, Boonstra and Krebs 1979, and others). The characteristic feature of multiannual cycles is the occurrence of the largest specimens, particularly males, during the peak density - the Chitty Effect (Chitty 1952, Chitty and Chitty 1962, Krebs 1964, Krebs and Myers 1974, Boonstra and Krebs 1979, and others).

Chitty $(1958,1967)$ proposed a genetic-behavioral hypothesis for explaining this phenomenon. It assumes a genetic basis in spacing behaviour traits and alternating selection for different genotypes as populations increase and decline, 
and has received close attention (Krebs 1964, 1966,1978; Krebs et al. 1969, 1976; Taitt and Krebs 1985, see Krebs and Myers 1974 and Gaines 1985 for review). The necessary genetic heritabilities for body weight, growth rate, age and weight at sexual maturity which are indispensable for determining the Chitty hypothesis, have not, however, been reported (Boonstra and Boag 1987). Although the Chitty Effect remains an interesting phenomenon its relevance to density fluctuations is questionable (Lidicker 1988).

The purpose of this paper is analysis of variations in body and skull size in relation to sex, age, dynamics of seasonal generations and population density in a free-living population of root voles in mountain habitats.

\section{Study area}

The study area is situated at Finse $\left(60^{\circ} 36^{\prime} \mathrm{N}, 7^{\circ} 30^{\prime} \mathrm{E}\right)$ in the northwestern part of the Hardangervidda mountain plateau in South central Norway (Fig. 1). Elevation of the trapping area is 1200 $-1400 \mathrm{~m}$ a. s. l. and includes the low and mid-alpine zone. The climate is mountain influenced, with cool summers and mild winters, with high precipitation the year round (Østbye et al. 1975). The vegetation mosaic has many phytosociological associations (Østbye et al. 1975). Most of the area (83\%) is covered by oligotrophic types of vegetation (Østbye et al. 1975).

Eight grids for trapping of small mammals were distributed in the gradient across the valley at Finse (Fig. 1). They were placed in four typical, relatively homogenous vegetation types: marshy

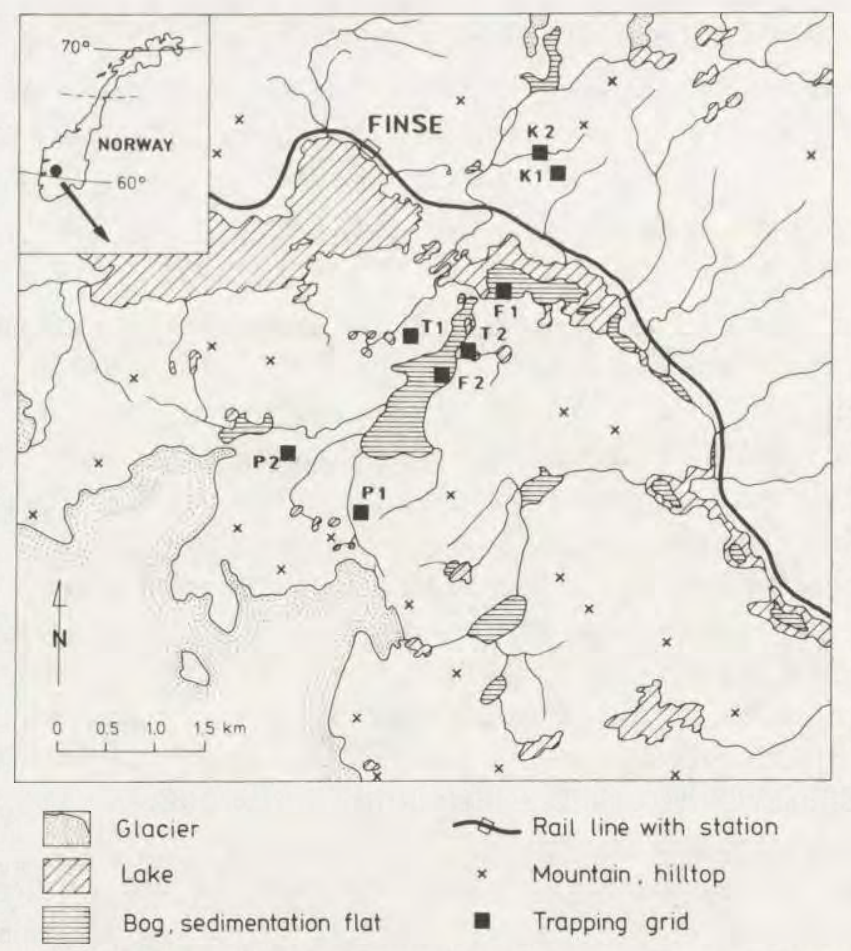

Fig. 1. Map of the study area at Finse. 
ground on sediment flats in the valley bottom (2 grids: F1, F2), southern exposed eutrophic meadows ( 2 grids: $\mathrm{K} 1, \mathrm{~K} 2$ ), northern exposed oligotrophic heath communities (2 grids: $\mathrm{T} 1, \mathrm{~T} 2$ ) and pioneer communities (2 grids: P1, P2).

Each grid consists of $10 \times 10$ trap stations placed every $10 \mathrm{~m}$. During the removal period, two snap traps were placed at each station and baited with wick or wool thread soaked in cooking oil. The trappings were carried out twice a year, just after snow melt in late June (so called "Spring sample"), and before regular snow fall in late August or early September ("Autumn sample"). The grids were worked for six days. In years with low density of rodents the trapping lasted only four days. Only three grids (K1, P1, T1) were used from 1970 through 1980. In years $1970-1972$ five additional grids were established. In 1974 grid K2 was trapped instead of K1 due to other trapping experiments.

\section{Materials and methods}

\section{Material}

Specimens were obtained during the period 1970 - 1978. A total of 915 specimens (Table 1) of the root vole were collected (E. Østbye, unpbl.). The animals were sexed, measured and weighed. The eye lenses were removed and fixed in $10 \%$ formaldehyde and used to determine age (Hagen et al. 1980). For further biometric investigations the heads of all specimens were taken and the skulls were cleaned using papain enzyme. Only 530 skulls were used for statistical analysis (Table 1) due to the high number of broken skulls as a result of using snap traps.

Following Markowski (1980), the available material was divided into 5 age classes according to morphological descriptive characters, development of crests, obliteration of suture and eye lens

Table 1. Total number of trapped root vole and number of specimens biometrically analysed in sex and age groups.

\begin{tabular}{|c|c|c|c|c|c|c|c|c|c|c|c|c|}
\hline \multirow{3}{*}{$\begin{array}{l}\text { Year and } \\
\text { season }\end{array}$} & \multirow{3}{*}{$\begin{array}{c}\text { Total } \\
\text { number } \\
\text { caught }\end{array}$} & \multicolumn{10}{|c|}{ Age groups } & \multirow{3}{*}{$\begin{array}{l}\text { Total } \\
\text { analysed }\end{array}$} \\
\hline & & \multicolumn{2}{|c|}{ I } & \multicolumn{2}{|c|}{ II } & \multicolumn{2}{|c|}{ III } & \multicolumn{2}{|c|}{ IV } & \multicolumn{2}{|c|}{$\mathrm{V}$} & \\
\hline & & M & F & M & F & M & F & M & $\mathrm{F}$ & M & F & \\
\hline $1970 \mathrm{~S}$ & 401 & 2 & 5 & 2 & 1 & 3 & & 2 & & 11 & 10 & 216 \\
\hline $1970 \mathrm{~A}$ & & 17 & 27 & 8 & 2 & 39 & 31 & 14 & 14 & 11 & 18 & \\
\hline $\begin{array}{l}1071 \mathrm{~S} \\
1971 \mathrm{~A}\end{array}$ & 3 & & & & & & & & & & & \\
\hline $\begin{array}{l}1972 \mathrm{~S} \\
1972 \mathrm{~A}\end{array}$ & 3 & & & & & 2 & 1 & & & & & 3 \\
\hline $1073 \mathrm{~S}$ & 126 & 2 & 2 & 2 & 1 & 3 & & 1 & 1 & 6 & 3 & 86 \\
\hline $1973 \mathrm{~A}$ & & 5 & 7 & 7 & & 24 & 8 & 6 & 5 & 3 & & \\
\hline $1974 \mathrm{~S}$ & 367 & 2 & 6 & 6 & 3 & 5 & 1 & 2 & 1 & 18 & 7 & 212 \\
\hline $1974 \mathrm{~A}$ & & 23 & 30 & 10 & 11 & 22 & 21 & 1 & 5 & 21 & 17 & \\
\hline $1977 \mathrm{~S}$ & 10 & & & & & & & & & & & \\
\hline 1977 A & & & & & & 3 & 1 & 2 & 2 & & & 8 \\
\hline $\begin{array}{l}1978 \mathrm{~S} \\
1978 \mathrm{~A}\end{array}$ & 5 & & & & & 1 & & & 2 & 2 & & 5 \\
\hline Total & 915 & 51 & 77 & 35 & 18 & 102 & 63 & 28 & 30 & 71 & 55 & 530 \\
\hline
\end{tabular}


weight: I - juveniles (up to one month), II - subadults ( 4 - 6 weeks), III - adults I ( 6 weeks to 3 months), IV - adults II ( 4 to 7 months), V - senex ( $>7$ months). The last age group consists of individuals caught in the second calendar year of their life.

\section{Measurements and indices}

The following four basic measurements were made : total length, head and body length (H \& BL), hind foot length (HFL) and body weight $\pm 0.5 \mathrm{~g}$ (E. Østbye, unpbl.). The total length was omitted from statistical calculations as it is rarely used in biomorphological studies, whereas the tail length (TL), which was calculated as a difference between total and head and body length, was used for each specimen.

Ten linear measurements were made on the skulls Markowski (1980): 1. Condylobasal length (CbL), 2. Brain-case length (BcL), 3. Diastema length (DL), 4. Maxillary tooth row length (MxTRL), 5. Mandibular length (MdL), 6. Brain-case breadth (BcB), 7. Zygomatic breadth (ZyB), 8. Interorbital constriction (IC), 9. Rostrum breadth (RB), 10. Brain-case height between bullae (BcH). These abbreviations are used throughout in the text.

Basic statistical parameters: mean $(\bar{x})$, standard deviation (SD), coefficient of variation (CV) were calculated for samples according to sex age classes and trapping periods. The differences between sexes were checked using the $t$-test. Variability within age groups and years was compared by computing the variance component for each skull measurement in one-way analysis of variance (Sokal and Rohlf 1981). All the calculations were made at the Computer Center of Łodz University using "Odra 1305" computer.

\section{Results}

\section{Fluctuating density pattern}

Cyclic variation in the density of the root vole is very distinct in the Hardangervidda area (Fig. 2). The population increased in 1969 and peaked in 1970 . There was a rapid decline in the spring 1971, however, as only a few specimens were caught. Through 1972 the population density remained low, whereas in 1973 there was an increase. In spring 1974, the density was moderate and then reached a very high value in the autumn. During the winter of $1974 / 1975$ a rapid decline

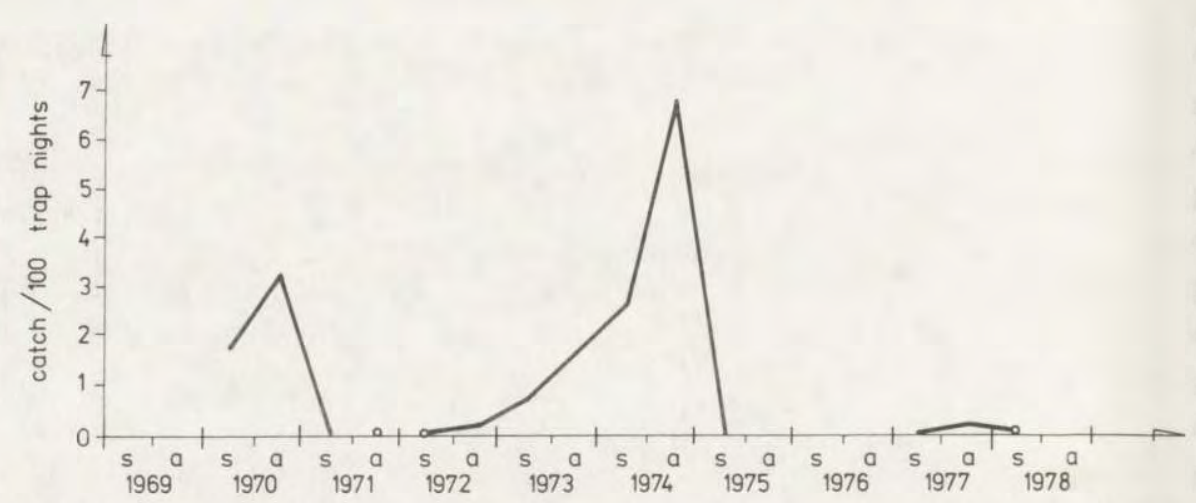

Fig. 2. Total captures of the root vole per 100 trap-nights for all traping grids in spring and autumn. Open circle - single specimens. 
was observed, and no root voles were caught in 1975 - 1976. In 1977, there was a slight increase in density to a pre-peak level in the autumn period. The population again declined during the winter of 1977/1978, and a few specimens were caught in the spring of 1978 (Fig. 2).

\section{Sexual dimorphism}

Sexual dimorphism is most clearly displayed in the oldest age group (senex), where the differences between mean values in most cases are highly statistically significant $(p<0.01)$ (Table 2$)$. These differences were smaller in younger classes, with only one measurement in class III. Males are statistically larger than females, except $\mathrm{ZyB}$ in class III. In our material no statistical differences were recorded between males and females or between age groups in the values of the coefficient of variation (two-way analysis of variance: $F_{(\mathrm{sex})}=0.587 \mathrm{~ns}, F_{\text {(age) }}=0.343 \mathrm{~ns}$, $F_{\text {(interaction) }}=0.191 \mathrm{~ns}$, for body dimensions; $F($ sex $)=0.912 \mathrm{~ns}, F_{(\text {age })}=470 \mathrm{~ns}$, $F$ (interaction) $=0.480 \mathrm{~ns}$, for skull dimensions. For females in age classes III and IV and males in age classes IV and V, almost all skulls and body dimensions are distinguished by their higher growth rates (Table 3 ).

\section{Age differentiation}

The results of one-way analysis of variance and Duncan multiple range test between all subsets of all age groups means in body and skull dimensions have shown statistically significant differences in most cases. There were some body measurements, such as tail, hind foot lengths and skull measurements $(\mathrm{BcH}, \mathrm{IC})$

Table 2. Comparisons of differences between males and females in different age groups. ${ }^{*},{ }^{* *}-$ differences significant at $p=0.05$ and $p=$ $0.01,+$ mean values higher for females.

\begin{tabular}{|c|c|c|c|c|c|}
\hline \multirow{2}{*}{ Measurements } & \multicolumn{5}{|c|}{ Age groups } \\
\hline & I & II & III & IV & V \\
\hline $\begin{array}{l}\text { Head and body length } \\
\text { Tail length }\end{array}$ & $* *$ & $* *$ & & & ** \\
\hline Hind foot length & * & & & ** & $* *$ \\
\hline Body weight & ** & & & ** & $* *$ \\
\hline $\mathrm{Cbl}$ & & ** & & & \\
\hline $\mathrm{Bcl}$ & & * & & & \\
\hline $\mathrm{DL}$ & $*$ & ** & & & \\
\hline MxTRL & & & & & \\
\hline Mdl & * & * & & $* *$ & ** \\
\hline $\mathrm{BcB}$ & & * & & $* *$ & \\
\hline $\mathrm{ZyB}$ & & $*$ & + & & ** \\
\hline IC & & & & $* *$ & \\
\hline RB & & & & & ** \\
\hline $\mathrm{BcH}$ & & & & & ** \\
\hline
\end{tabular}


Table 3. Increase in body and skull dimensions in different age groups for males and females (\%). The mean values for age group I were taken as $100 \%$. M - males, $\mathrm{F}-$ females.

\begin{tabular}{|c|c|c|c|c|c|c|c|c|}
\hline \multirow{3}{*}{ Measurements } & \multicolumn{8}{|c|}{ Age groups } \\
\hline & \multicolumn{2}{|r|}{ II } & \multicolumn{2}{|c|}{ III } & \multicolumn{2}{|r|}{ IV } & \multicolumn{2}{|r|}{ V } \\
\hline & M & F & M & $\mathrm{F}$ & M & F & M & $\mathrm{F}$ \\
\hline $\mathrm{H} \& \mathrm{BL}$ & 4.13 & -0.56 & 9.60 & 29.95 & 28.16 & 34.07 & 35.36 & 38.43 \\
\hline $\mathrm{TL}$ & 5.21 & 3.33 & 7.33 & 13.86 & 28.09 & 31.62 & 28.58 & 31.28 \\
\hline HFL & -2.11 & 2.76 & 0.65 & 3.32 & 5.85 & 3.30 & 3.87 & 2.99 \\
\hline Body weight & 14.52 & 14.22 & 37.34 & 58.61 & 143.09 & 128.81 & 190.28 & 166.67 \\
\hline $\mathrm{CbL}$ & 5.65 & 4.01 & 9.15 & 12.25 & 20.38 & 20.52 & 26.85 & 23.93 \\
\hline $\mathrm{BcL}$ & 3.42 & 3.15 & 6.16 & 9.88 & 16.69 & 17.93 & 22.36 & 20.01 \\
\hline $\mathrm{DL}$ & 4.12 & 2.42 & 7.72 & 10.35 & 19.37 & 19.55 & 27.43 & 23.02 \\
\hline MxTRL & 2.51 & 1.39 & 4.89 & 4.49 & 10.69 & 8.62 & 12.63 & 11.41 \\
\hline MdL & 3.34 & 2.26 & 6.06 & 8.86 & 15.91 & 16.14 & 21.60 & 20.17 \\
\hline $\mathrm{BcB}$ & 2.63 & 1.03 & 4.75 & 6.37 & 13.64 & 12.19 & 18.52 & 16.84 \\
\hline $\mathrm{ZyB}$ & 2.85 & 0.72 & 5.12 & 9.22 & 20.85 & 20.39 & 28.22 & 27.68 \\
\hline IC & 2.40 & 2.08 & 1.92 & 2.35 & 5.61 & 2.17 & 3.76 & 3.15 \\
\hline $\mathrm{RB}$ & 2.81 & 1.73 & 5.70 & 6.92 & 18.74 & 16.81 & 23.31 & 17.07 \\
\hline $\mathrm{BcH}$ & 1.33 & -0.40 & 1.64 & 2.95 & 7.46 & 6.15 & 8.42 & 6.90 \\
\hline
\end{tabular}

Table 4. Results of analysis of variance in body and skull dimensions between five age groups (I V) of males and females. Non-significant subsets of averages underlined.

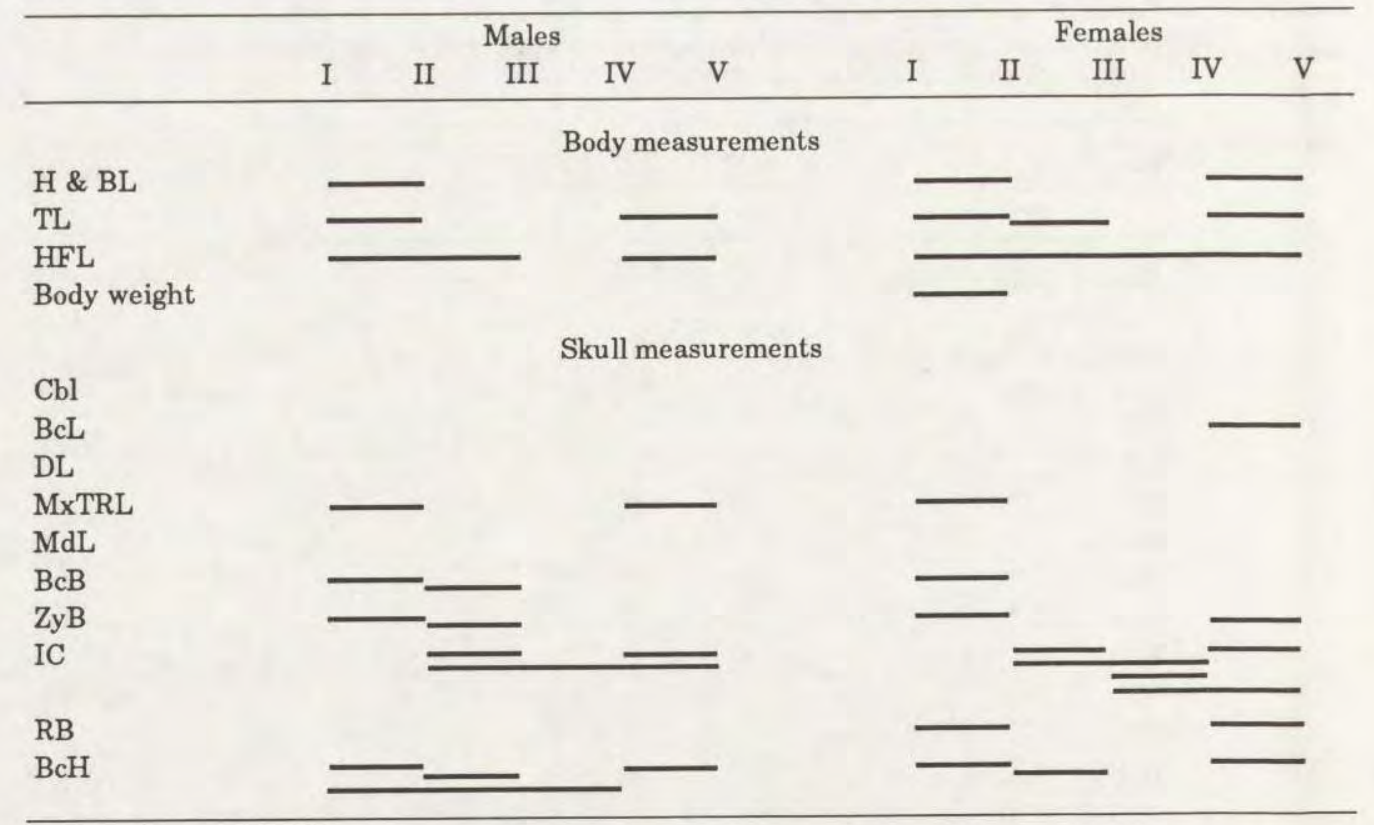


Table 5. Comparisons of significance of differences in mean values of body and skull dimensions in the spring and autumn generations in age groups using $t$ - test at $p=0.05$. Mean values higher in the spring generation are underlined. s - significant, ns - not significant.

\begin{tabular}{|c|c|c|c|c|c|c|}
\hline \multirow{2}{*}{ Measurements } & \multicolumn{6}{|c|}{ Age groups } \\
\hline & I & $\begin{array}{c}\text { II } \\
\text { Males }\end{array}$ & III & I & $\begin{array}{c}\text { II } \\
\text { Females }\end{array}$ & III \\
\hline $\mathrm{H} \& \mathrm{BL}$ & & ns & ns & ns & & \\
\hline $\mathrm{TL}$ & $\mathbf{s}$ & ns & $\mathrm{ns}$ & ns & & \\
\hline HFL & $\mathbf{s}$ & ns & $\mathrm{ns}$ & $\mathrm{s}$ & & \\
\hline Body weight & ns & ns & ns & $\mathrm{ns}$ & & \\
\hline $\mathrm{CbL}$ & & & ns & & & \\
\hline $\mathrm{BcL}$ & & & ns & & & \\
\hline $\mathrm{DL}$ & ns & ns & ns & $\mathrm{ns}$ & ns & \\
\hline MxTRL & ns & ns & ns & ns & ns & \\
\hline $\mathrm{MdL}$ & ns & ns & ns & ns & ns & \\
\hline $\mathrm{BcB}$ & & & & & & \\
\hline $\mathrm{ZyB}$ & & $\mathrm{ns}$ & $\mathrm{ns}$ & ns & & \\
\hline IC & ns & ns & ns & ns & ns & \\
\hline $\mathrm{RB}$ & ns & ns & ns & ns & ns & \\
\hline $\mathrm{BcH}$ & & ns & ns & & & \\
\hline
\end{tabular}

Table 6. Sex differences within each of the seasonal generations in adequate age groups (I - III) using $t$-test at $p=0.05$. Mean values higher for males are underlined.

\begin{tabular}{|c|c|c|c|c|c|c|}
\hline \multirow{2}{*}{ Measurements } & \multicolumn{3}{|c|}{ Spring generation } & \multicolumn{3}{|c|}{ Autumn generation } \\
\hline & I & II & III & I & II & III \\
\hline $\mathrm{H} \& \mathrm{BL}$ & ns & & $\mathrm{ns}$ & $\mathrm{s}$ & & ns \\
\hline TL & $\mathrm{s}$ & & & ns & & $\mathrm{ns}$ \\
\hline HFL & ns & & & ns & & ns \\
\hline Body weight & ns & & & ns & $\mathrm{s}$ & ns \\
\hline $\mathrm{CbL}$ & & & & ns & $\mathbf{s}$ & $\mathrm{ns}$ \\
\hline $\mathrm{BcL}$ & & & & ns & ns & $\mathrm{ns}$ \\
\hline $\mathrm{DL}$ & & ns & ns & ns & ns & $\mathrm{ns}$ \\
\hline MxTRL & & ns & $\mathrm{ns}$ & ns & ns & $\mathrm{ns}$ \\
\hline $\mathrm{MdL}$ & & ns & $\mathrm{ns}$ & $\mathbf{s}$ & $\mathbf{s}$ & $\mathrm{ns}$ \\
\hline $\mathrm{BcB}$ & & & & ns & ns & $\mathrm{ns}$ \\
\hline $\mathrm{ZyB}$ & & & & $\mathrm{ns}$ & s & $\mathrm{s}$ \\
\hline IC & & ns & $\mathrm{ns}$ & ns & ns & ns \\
\hline $\mathrm{RB}$ & & ns & $\mathrm{ns}$ & ns & ns & \\
\hline $\mathrm{BcH}$ & & & & ns & s & $\mathrm{ns}$ \\
\hline
\end{tabular}


Table 7. Distribution of Microtus oeconomus individuals according to eye lens weight.

\begin{tabular}{|c|c|c|c|c|c|c|c|c|c|c|c|c|c|}
\hline \multirow{2}{*}{$\begin{array}{l}\text { Year and } \\
\text { season }\end{array}$} & \multirow{2}{*}{ Sex } & \multicolumn{12}{|c|}{ Eye lens weight (mg) } \\
\hline & & $>1.5$ & 2.0 & 2.5 & 3.0 & 3.5 & 4.0 & 4.5 & 5.0 & 5.5 & 6.0 & 6.5 & 6.5 \\
\hline \multicolumn{14}{|l|}{1969} \\
\hline \multirow[t]{2}{*}{ Spring } & M & & 1 & & 1 & & & & 1 & & & & \\
\hline & F & & 1 & 1 & & & & & 1 & 1 & & & \\
\hline \multirow[t]{2}{*}{ Autumn } & $\mathrm{M}$ & 1 & 2 & 4 & 3 & 9 & 5 & & 2 & & & & \\
\hline & $\mathrm{F}$ & 4 & 1 & 6 & 8 & 6 & 2 & 2 & 2 & & & & \\
\hline \multicolumn{14}{|l|}{1970} \\
\hline \multirow[t]{2}{*}{ Spring } & M & & 7 & 6 & 4 & 1 & & & 3 & 7 & 14 & 5 & 4 \\
\hline & $F$ & 3 & 11 & 10 & 2 & & 1 & 2 & 1 & 11 & 14 & 2 & 1 \\
\hline \multirow[t]{2}{*}{ Autumn } & M & 2 & 20 & 41 & 47 & 50 & 28 & 12 & 4 & 5 & 13 & 5 & 9 \\
\hline & $\mathrm{F}$ & 2 & 22 & 59 & 48 & 42 & 38 & 7 & 7 & 13 & 16 & 9 & 2 \\
\hline \multicolumn{14}{|l|}{1973} \\
\hline \multirow[t]{2}{*}{ Spring } & M & 1 & 3 & 11 & 7 & & & 1 & 1 & 3 & 7 & & \\
\hline & $\mathrm{F}$ & 1 & 3 & 4 & & & & & 5 & & 1 & 1 & \\
\hline \multirow[t]{2}{*}{ Autumn } & M & & 9 & 18 & 46 & 17 & 11 & 1 & & & 1 & & \\
\hline & F & & 8 & 21 & 11 & 20 & 5 & 1 & & 2 & & & \\
\hline \multicolumn{14}{|l|}{1974} \\
\hline \multirow[t]{2}{*}{ Spring } & $\mathrm{M}$ & & 7 & 16 & 11 & 3 & 1 & & 1 & 10 & 17 & 3 & \\
\hline & $\mathrm{F}$ & & 6 & 18 & 10 & 1 & & & 6 & 14 & 6 & & \\
\hline \multirow[t]{2}{*}{ Autumn } & M & & 5 & 31 & 27 & 22 & & & 1 & 3 & 10 & 12 & \\
\hline & $\mathrm{F}$ & 1 & 13 & 36 & 22 & 13 & 7 & 1 & 3 & 10 & 10 & 3 & 1 \\
\hline
\end{tabular}

Table 8. Percentage frequencies of males and females in the youngest and overwintering class of the root vole. ${ }^{*},{ }^{* *}$ - differences significant at $p=0.05$ and $p=0.01$ between sexes within groups.

\begin{tabular}{lllll}
\hline & \multicolumn{4}{c}{ Years } \\
\cline { 2 - 5 } Eye lens weight & $\begin{array}{c}1969 \\
\mathrm{n}=64\end{array}$ & $\begin{array}{c}1970 \\
\mathrm{n}=610\end{array}$ & $\begin{array}{c}1973 \\
\mathrm{n}=228\end{array}$ & $\begin{array}{c}1974 \\
\mathrm{n}=370\end{array}$ \\
\hline up to $2.5 \mathrm{mg}$ & & & & \\
Male & $26.7^{*}$ & $26.5^{* *}$ & $30.7^{* *}$ & $31.7^{* *}$ \\
Female & 38.2 & 33.1 & 47.0 & 38.1 \\
Male + Female & 32.8 & 30.0 & 34.7 & 34.9 \\
over 4.5 mg & & & & \\
Male & 10.0 & 24.0 & 8.6 & 30.3 \\
Female & 11.8 & 22.6 & 10.2 & 29.4 \\
Male + Female & 10.9 & 23.3 & 9.2 & 29.9 \\
\hline
\end{tabular}


where the number of differences among means was lower. Also, the number of differences in means between the sexes was similar (Table 4).

Variability of seasonal generations

The $t$-test was used to check differences in means of the body and skull dimensions in the spring and autumn generations. Because the material from spring trapping periods was scarce the comparisons were limited. Both sexes were treated separately according to the differences in the growth rate of this species as documented by Kratochvil and Rosicky (1955), Karaseeva et al. (1957), Snigirevskaja (1961) and Markowski (1980). Statistically significant differences were shown in only three mesurements. However, most means values of body and skull dimensions were higher for the spring specimens (Table 5).

The differences in mean values of body and skull dimensions between sexes within each of the generations were tested using the $t$-test at the $p=0.05$ level of significance. Limited possibilities to test the spring generation (too scarce material) precluded the occurrence of statistical differences. In the autumn generation most statistically significant differences were in the second age group, where males had higher mean values than females. In the other age classes most differences were not statistically significant; mean body and skull dimensions were, however, higher for females (Table 6).

Between - year differences

One way analysis of variance and Duncan test of equality of means were used to compare the mean values of body and skull measurements in subsequent years. Males and females were treated separately. Body dimensions, such as: body, tail and hind foot lengths were not recorded in 1974, so they were not used in the analysis of variance. Neither does the present analysis include the scarce material from 1977 and 1978.

The results obtained suggest few differences between the compared years. Hence, of 15 pairwise comparisons of body weight, only two were statistically significant for males and only two for females. Also, in the skull dimensions and quotient indices most comparisons were not statistically significant.

\section{Weight of eye lenses}

The distributions of the weight of eye lenses were bimodal for both sexes; however, they differed in their peak values. The first peak occurs at $2.5 \mathrm{mg}$, the second at $5.5 \mathrm{mg}$ for females, and 3.0 and $6.0 \mathrm{mg}$ for males (Fig. 3). The clear bimodality in the distribution of eye lens weights reflects the two major cohorts in the samples; overwintered and young of the year (see Table 7).

No intersexual differences in the distribution of eye lens weights were apparent (Kolmogorov-Smirnov test). However, restricting the sample to eye lens weight $>4.5 \mathrm{mg}$, significant differences between the sexes were found in autumn 1973, spring $1974(p<0.05)$ and for the whole year of $1974(p<0.01)$. Interseasonal 
differences in distributions of eye lens weights for each sexes were statistically significant $(p<0.05)$ between years $1970-1974$ and $1973-1974$ in both sexes of young animals.

Percentage frequencies of overwintering specimens were more variable than the frequencies of quite young ones (up to $2.5 \mathrm{mg}$ of eye lens weight). Particularly high frequencies of overwintering specimens were noted for the peaks in 1970 and 1974 (Table 8). The differences in frequencies between males and females of overwintering animals did not exceed $2 \%$, while for the young ones females, lens weights were higher, and statistically significantly so $(p<0.05)$, in the years of increased densities, when the domination of females was observed (see Table 8).

\section{Body weight}

The bimodality of the body weight frequency distribution in both sexes reflects the distinction between overwintering and current years' individuals. The first peak occurs at $20 \mathrm{~g}$ for both sexes, the second peak occurs at $40 \mathrm{~g}$ for females and at $55 \mathrm{~g}$ for males (Fig. $4 \mathrm{a}$ ).

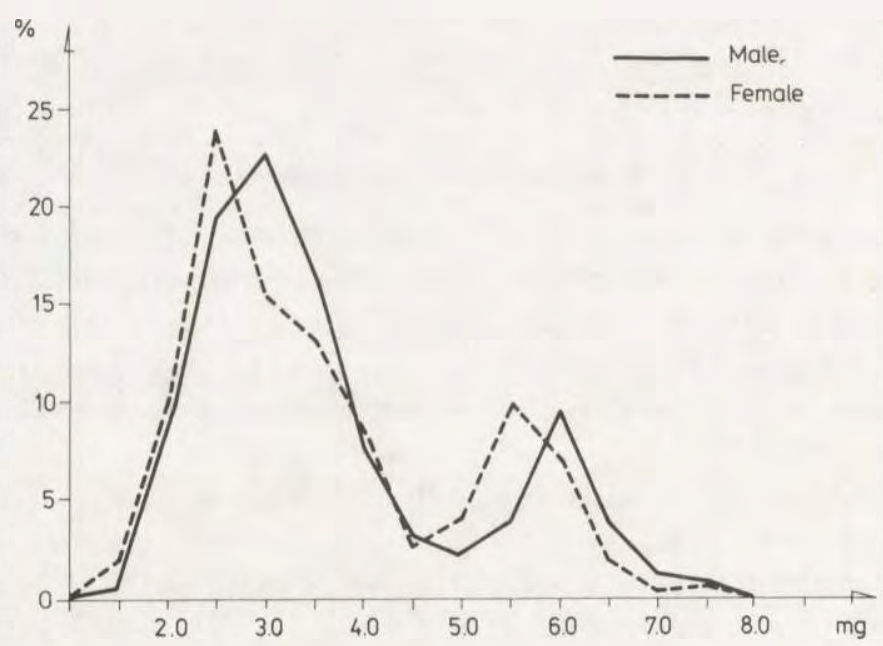

Fig. 3. Frequency distribution of dry eye lens weight in males and females.

Table 9. Statistical description of body weight in overwintering females in spring trapping.

\begin{tabular}{cccccc}
\hline Year & N & Min. $-\max$. & $\bar{x}$ & SD & CV \\
\hline 1969 & 16 & $28.0-63.0$ & 42.53 & 9.86 & 23.18 \\
1970 & 41 & $25.0-63.0$ & 44.59 & 7.35 & 16.48 \\
1973 & 10 & $37.0-57.0$ & 43.78 & 5.78 & 13.21 \\
1974 & 25 & $34.0-67.0$ & 49.24 & 7.11 & 14.44 \\
\hline
\end{tabular}



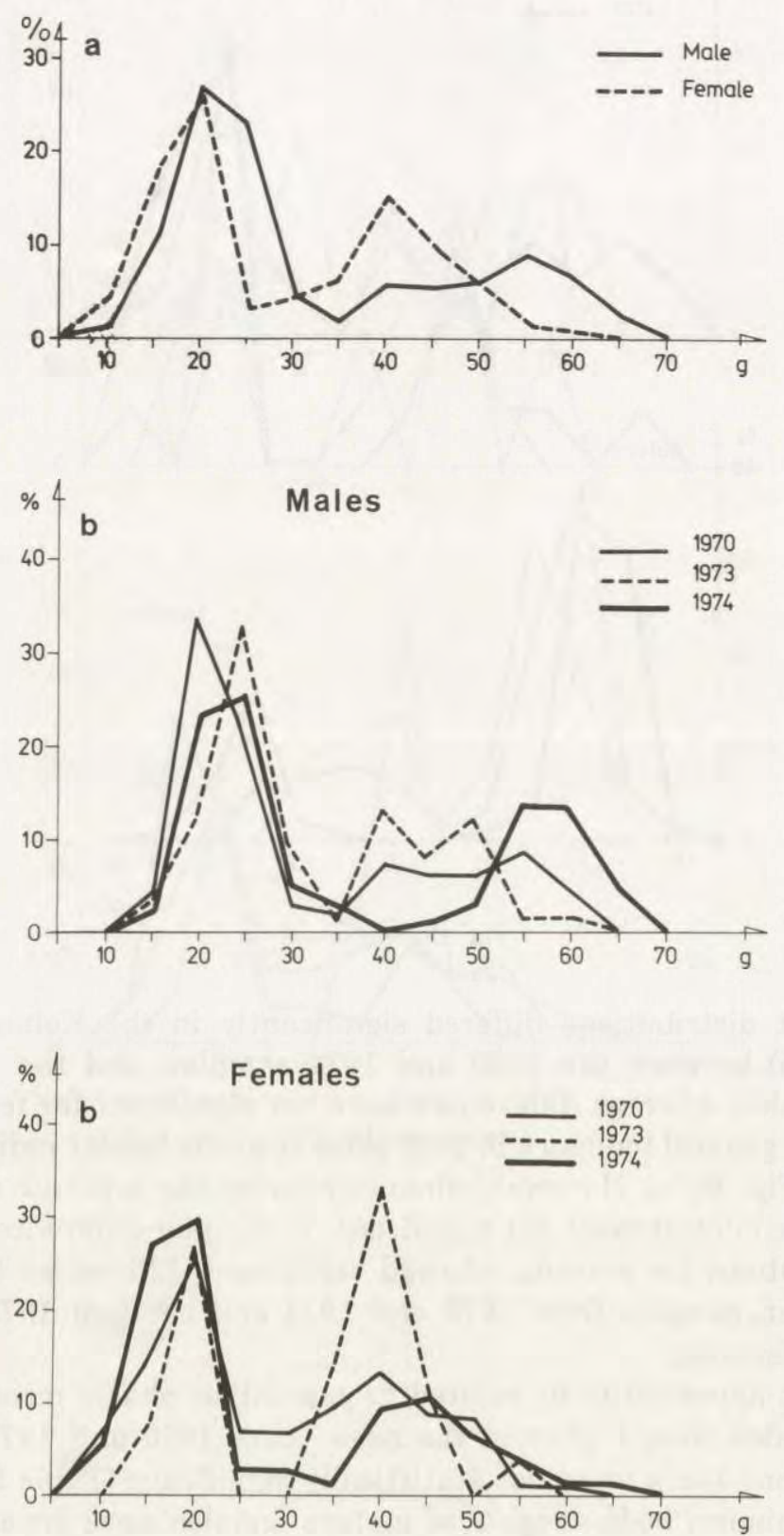

Fig. 4. Frequency distribution of body weight for males and females (a), in successive study years for males and females (b), in trapping seasons of successive years for males (c), and females (d). This Figure is continued on next pages. 

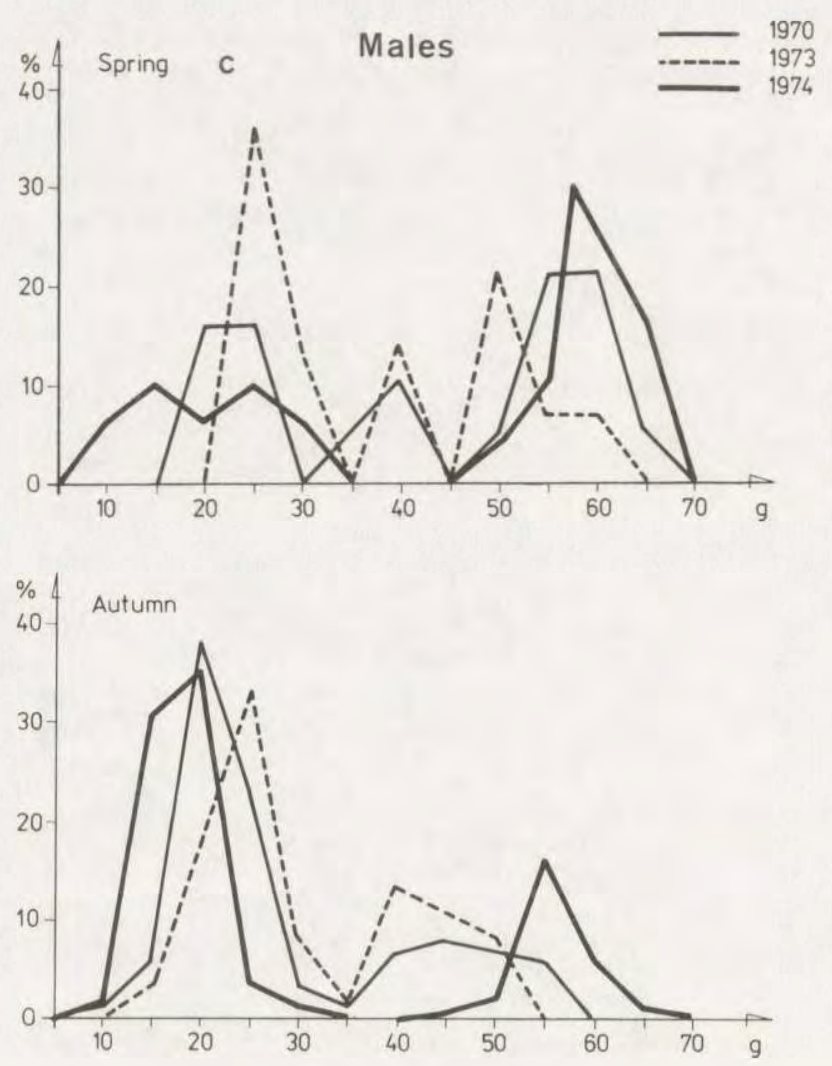

Fig. 4c, continued.

Body weight distributions differed significantly in the Kolmogorov-Smirnov tests $(p<0.05)$ between the 1973 and 1974 samples, and the 1970 and 1974 samples for males, whereas differences were not significant for females.

There was a general tendency in both sexes towards lighter individuals in 1973 than in 1974 (Fig. 4b, c). However, when comparing the separate age classes, the differences were in most cases not significant. Testing for differences between body weight distributions by seasons, showed significant differences $(p<0.05)$ only between autumn samples from 1970 and 1974 and between 1973 and 1974 for males and for females.

Body weight appeared to be related to population phase; mean body weights of mature females were higher in the peak years 1970 and 1974, however the differences among them were not statistically significant (Table 9). In the same peak years minimum body weights of mature females were lowest. The highest body weights were found during the maximum peak density (1974). Monthly trappings from December 1973 to May 1974 (E. Østbye, unpubl.) showed loss of body weight during autumn and winter periods (Fig. 5). 

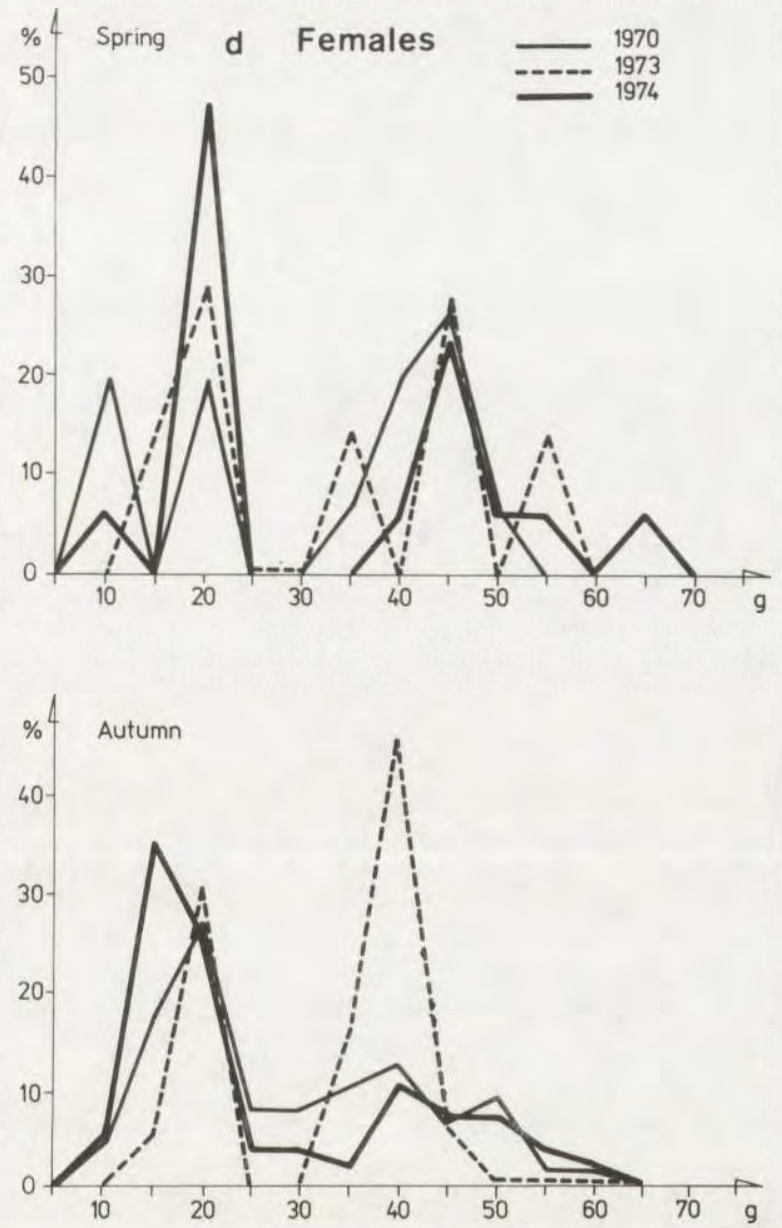

Fig. 4d, concluded.

Fig. 5. Changes in mean body weight during the winter season for males and females.

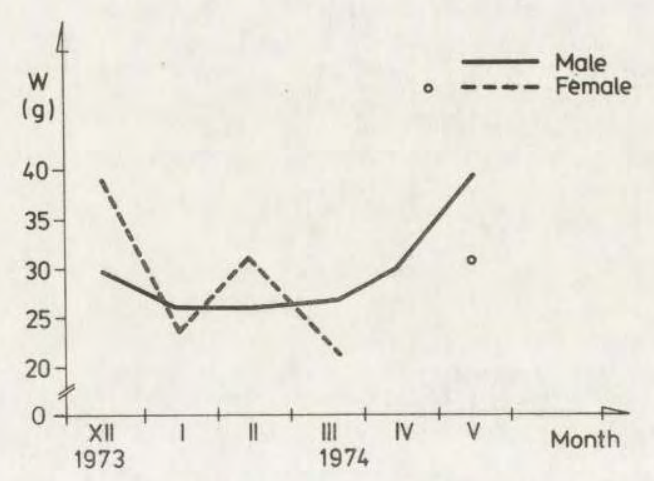



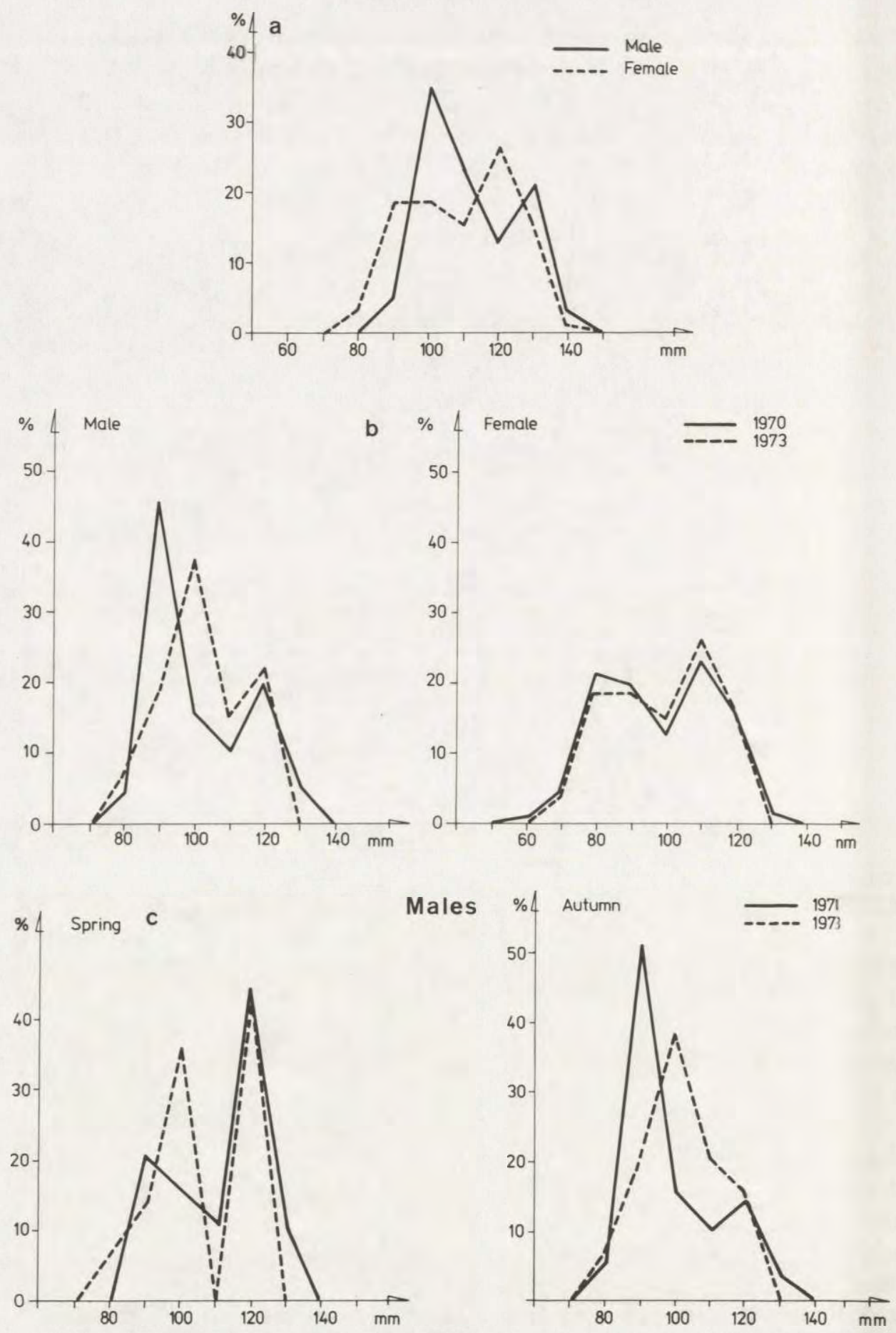

Fig. 6. 

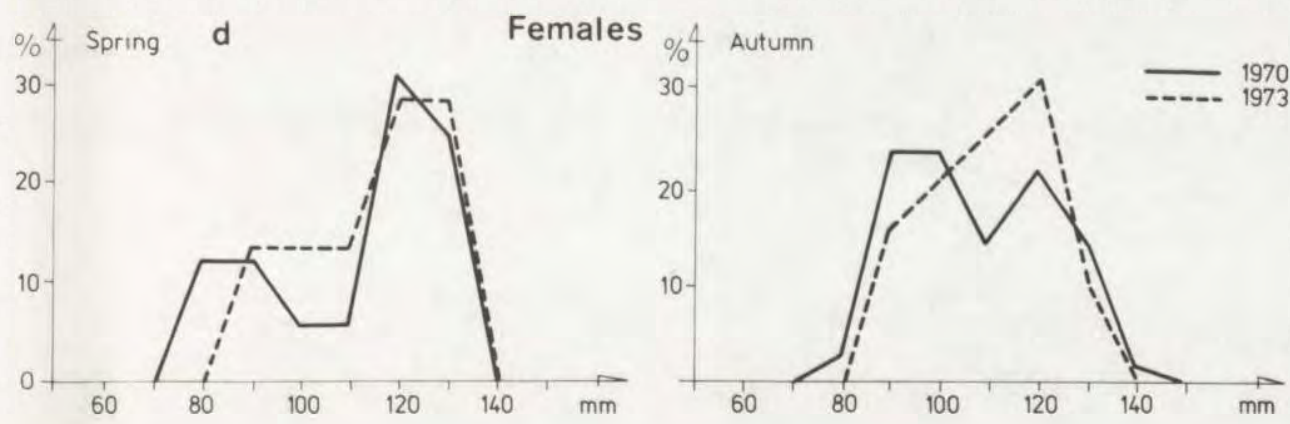

Fig. 6. Frequency distribution of body length for males and females (a), in successive study years for males and females (b), in trapping seasons of successive years for males (c), and females (d).

\section{Body length}

The distributions of the body length frequencies were bimodal for both sexes: the first peak at $90 \mathrm{~mm}$ and $100 \mathrm{~mm}$, the second peak at $120 \mathrm{~mm}$ and $130 \mathrm{~mm}$ for females and males, respectively (Fig. 6a). As body measurements were not taken in 1974 inter a years comparisons were restricted to 1970 and 1973 . The distributions of body length frequencies for both years were similar for females, while in males, the first modal peak in 1973 was higher than in 1970 (Fig. 6b).

In the spring sample the bimodal distribution in body length was distinct for males, but less so for females. The autumn samples from 1970 and 1973 differed; body length distribution was bimodal in 1970, but uni-modal in 1973 for both sexes (Fig. 6c, d).

Differences between distributions of body length tested by the KolmogorovSmirnov test showed no significant differences between years and seasons of years for each of the sexes.

\section{Condylobasal length}

The distributions of the condylobasal length frequencies showed the same bimodal distribution as did the two previously analysed parameters, though the first peak was not as distinct as for body weight and body length distribution. The second peak for condylobasal length was at $26 \mathrm{~mm}$ for females and $28 \mathrm{~mm}$ for males (Fig. 7a).

CbL distributions differed significantly in the Kolmogorov-Smirnov tests ( $p<$ 0.05 ) between the 1970 and 1974 samples, and autumn samples the 1970 and 1974 for females, whereas no statistical differences were found for males. Cb length distributions were significantly different $(p<0.05)$ between sexes in spring, whereas no significant differences were found in the autumn seasons.

The distributions of this measurement in successive years differed for both sexes, not only by the value of peaks but also by the character of distribution (Fig. $7 \mathrm{~b})$. This is due to a large number of autumn specimens (Fig. 7c, $\mathrm{d}$ for comparisons). 
132
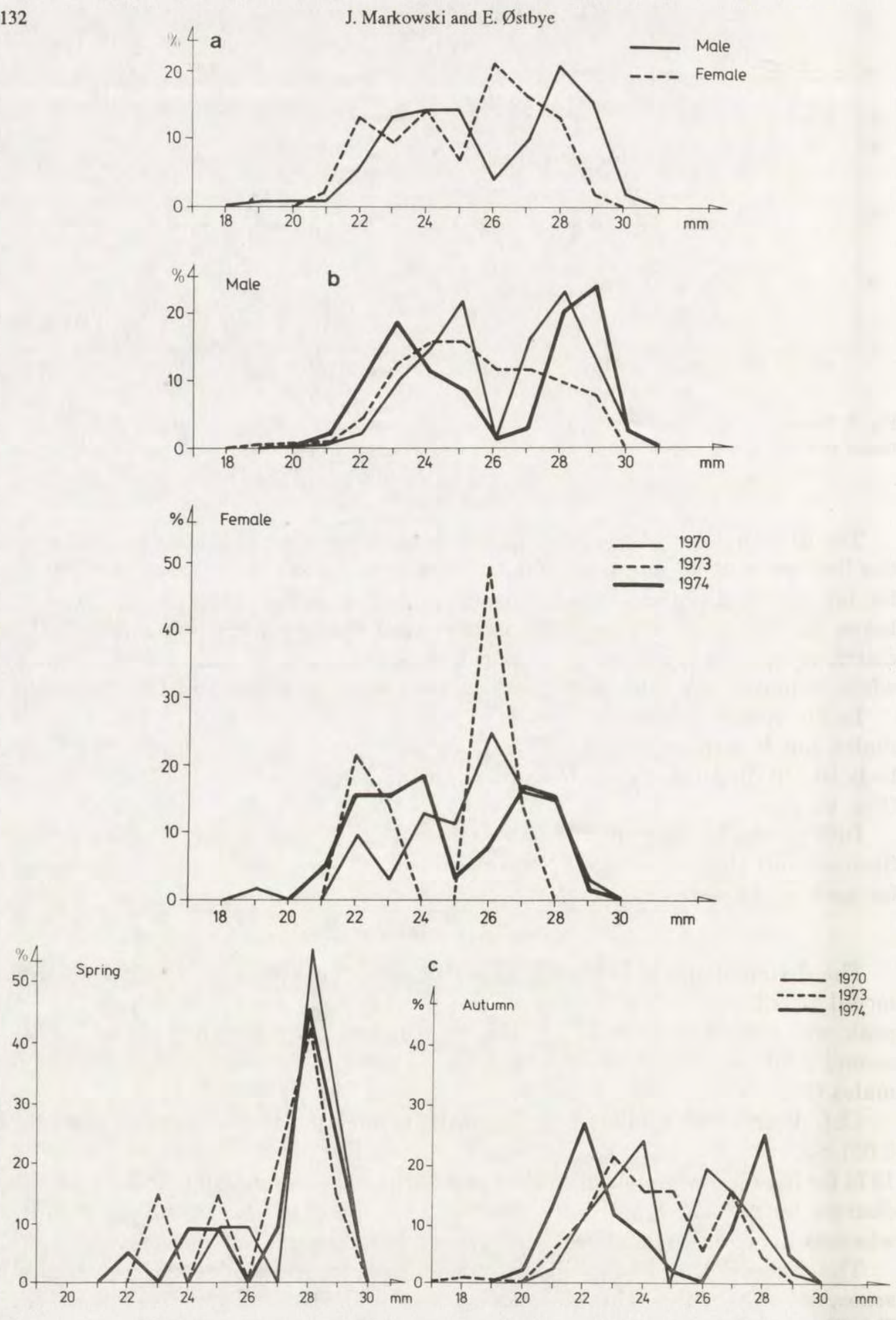

Fig. 7. 

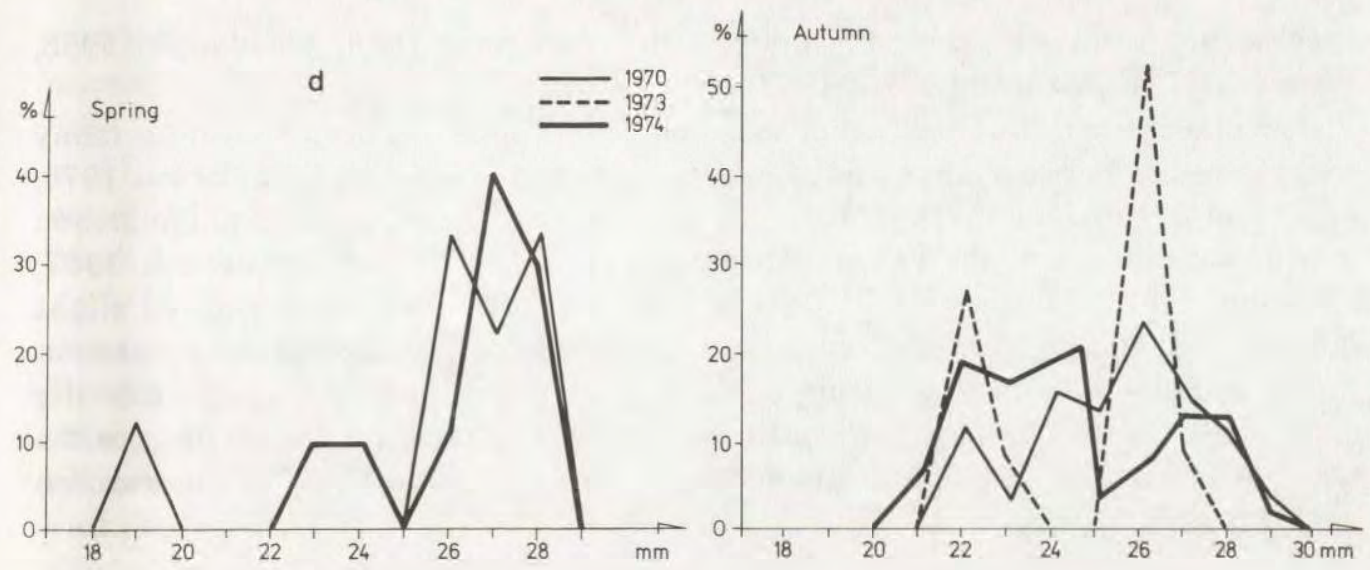

Fig. 7. Frequency distribution of condylobasal length for males and females (a), in successive study years for males and females (b), in trapping seasons of successive years for males (c), and females (d).

\section{Discussion}

Although the data on sex dimorphism in the root vole are divergent, most authors have shown larger body and skull dimensions for males (Dehnel 1946, Ehik 1953, Bauer 1953, Kratochvíl and Rosicky 1955, Saint-Girons and Mazàk 1971, Bashenina 1977, Markowski 1980); see however Wasilewski 1956 and Kanep 1967.

Kratochvil and Rosicky (1955) have suggested that larger males were a result of better survival allowing them to reach larger body size. The different survival of both sexes of the root vole due to season and phases of populational cycles is indicated by Markowski (1980). Analysis of age structure of the study population, based on eye lens weight only, though limited to increase and peak phases, has shown that the overwintering males are older than females (see Table 7). This supports Kratochvil and Rosicky's thesis. This phenomenon is well known for other microtine species with fluctuating populations (Chitty and Phipps 1966, Krebs and Myers 1974), though males do not survive better than females in all cases (Krebs and Myers 1974, Beacham 1979).

Body size of the root vole is affected by other factors such as time of birth, which is closely associated with sexual maturity (Karaseeva et al. 1957, Bojkova and Bojkov 1971 after Panteleyev and Terechina 1976, Wasilewski 1956, Schwarz et al. 1964, Markowski 1980). Recently, Bondrup-Nielsen and Ims (1990) presented a reversed sexual size dimorphism hypothesis in microtines. They suggest that the relationship between home range size and body weight dimorphism reflects different selection pressures on males and females in competition for resources.

Thus sex dimorphism could be viewed relative to the conditions in which a given population occurs. It would then appear that ignoring the above mentioned facts may lead to discrepancies in the data on the sex dimorphism of some vole 
species (see Ruprecht 1974, Pantaleyev and Teerchina 1976, Wasilewski 1956, Kanep 1967, Gębczyńska 1964, 1967).

Morphological differentiation of seasonal generations has been shown for many rodent species to occur at regular intervals (Schwarz et al. 1964, Anderson 1970, and others). Previous investigations on the root vole supported this phenomenon in different parts of its range (Karaseeva et al. 1957, Schwarz et al. 1967, Pjastolova 1971, Markowski 1980), whereas the study population showed slight differentiation. This results from a poor representation of the spring generation in the samples because the spring samples were predominated by overwintering specimens. The individuals born in the spring were usually immature despite the fact that their body and skull dimensions were larger than those of the autumn generation.

Table 10. Cumulative percentage increase in selected body and skull dimensions in the root vole in different age classes (both sexes) in relation to the trapping year. The mean values for age class I were taken as $100 \%$.

\begin{tabular}{llrrrr}
\hline & & \multicolumn{5}{c}{ Age classes } \\
\cline { 3 - 6 } Measurements & Sex & II & III & IV & V \\
\hline \multirow{2}{*}{ 1970 } & & & & & \\
Body weight & M & 13.8 & 23.5 & 132.7 & 168.9 \\
& F & 19.1 & 54.7 & 124.4 & 167.7 \\
Head \& Body length & M & 2.2 & 5.3 & 28.7 & 34.7 \\
& F & & 20.1 & 34.3 & 41.5 \\
CbL & M & 9.5 & 7.7 & 19.9 & 25.0 \\
& F & & 14.5 & 22.9 & 26.4 \\
MdL & M & 3.2 & 5.0 & 15.5 & 20.9 \\
& F & & 7.7 & 13.6 & 18.8 \\
1973 & & & & & \\
Body weight & M & 9.1 & 37.4 & 88.4 & 127.6 \\
& F & 14.9 & 92.7 & 102.6 & 123.4 \\
Head \& Body length & M & 6.4 & 16.0 & 26.2 & 36.7 \\
& F & 2.7 & 22.6 & 23.6 & 28.9 \\
CbL & M & 4.0 & 10.4 & 19.0 & 23.4 \\
& F & 3.6 & 15.7 & 16.2 & 17.5 \\
MdL & M & 4.9 & 7.8 & 13.3 & 22.3 \\
& F & & 9.5 & 12.3 & 16.0 \\
1974 & & & & & \\
Body weight & M & 11.9 & 32.4 & 243.3 & 238.2 \\
& F & 13.6 & 38.8 & 147.8 & 182.5 \\
CbL & M & 5.7 & 8.6 & 18.8 & 28.2 \\
MdL & F & 3.4 & 9.5 & 21.5 & 24.0 \\
& F & 3.0 & 5.9 & 17.3 & 22.4 \\
& & 4.7 & 9.3 & 20.0 & 22.6 \\
\hline & & & & &
\end{tabular}


The root vole at Finse was found to lose body weight during the autumn and winter (Fig. 5). This is well known for other microtine species (Karaseeva et al. 1957, Schwarz et al. 1964, Brown 1973, Iverson and Turner 1974, and others), and has been called the Dehnel phenomenon occurring as an adaptation to winter conditions, in which a smaller body size may be favourable (Schwarz 1962, Mezhzherin 1964). Tast (1972) attributed the loss of body weight from autumn to early winter in a root vole population in north Finland to higher mortality in sexually mature individuals from the previous summer. On the other hand Beacham (1980) found that body weight increased during a pre-peak winter in Microtus townsendii. Thus, winter weight loss in voles is not a general feature of all microtine species during populational cycles. Also, winter breeding, although rather rarely noted in root vole populations (Tast 1976, Hagen et al. 1975), could cause increased body weight.

Chitty (1952) was the first to describe peak populations of voles, typically containing $20-30 \%$ of adults, especially males, which are larger than adults during low or declining populations. This phenomenon, known as The Chitty Effect, has been regarded as a characteristic feature of multiannual cycles in microtines (Chitty and Chitty 1962, Krebs 1964, Krebs and Myers 1974, Boonstra and Krebs 1979, Taitt and Krebs 1985). The larger specimens are not only older or fatter individuals, but show skeletal change (Zimmermann 1955, Krebs 1964).

Chitty (1967) suggested that this phenomenon could be based on genetic polymorhism for body size and that large individuals were selected during population increases and peaks. Gaines (1985) concluded, however, that such changes seemed to be an effect, not a cause of density changes. Also Boonstra and Boag (1987) showed that the heritabilities of morphological traits are too low for natural selection to produce the body size-change syndrome characteristic of microtine cycles.

Krebs and Myers (1974) presented three possible ways of relating changes in body size to population density: 1) during the increase and peak phases voles live longer and attain maximum body size; 2 ) voles grow more rapidly during increase and peak phases than during decrease phases (this assumes that animals of the same age are larger in increase and peak phases); 3) the growth rate of young specimens may be identical in each year of the population cycle, but their maximum weight may differ with cycle phases.

The first hypothesis associated with changes in age structure is based on differential survival of male and female cohorts. Our data indirectly support (analysis of given classes of eye lens weight, percentages) greater survival, especially of males at the peak phase of density (Table 7). Despite many controversial opinions about survival, numerous data support better survival in the increase and especially peak phase (see Krebs and Myers 1974, Beacham 1979, and others). Vole body size increased from increase phase to the peak density (Chitty Effect) and the higher the peak, the larger the body size and higher the percentage frequencies of overwintering individuals (Table 8). A similar effect was 
recorded by Markowski (1990) in the fluctuating population of the root vole in a drained sphagnum bog (Augustów Forest, northeastern Poland) before its numbers decreased nearly to extinction.

In our case the second and third hypotheses are difficult to verify due to the way the material was collected. The recorded higher increases in many body and skull dimensions in the years of peak density (Table 10) might be attributed to variability of growth rates of overwintering and current years' individuals. The specimens of class II and III have lower growth rates in peak years. However, the possibility of influence of season (birth time) has to be considered and time of sexual maturity and data on instantaneous growth rates would be indispensable in solving this problem. Some of the observed variabilities in body size and other biological characters in the peak density, such as: growth rates of young specimens, mean body weight of sexually mature overwintering females (Table 9) are partially adjusted to the $\alpha$-selected types hypothesis (Stenseth 1978).

Karaseeva et al. (1957) in their study on the root vole population, and also other studies on microtine species (Krebs 1969, Krebs et al. 1973, Krebs and Myers 1974), attributed the highest growth rates to increase and peak phases. Modelling of small rodents' populational cycles at Finse in previous years Hagen et al. (1975) determined for young voles that the maximum growth rates were lower and growth was much reduced in winter. For adults the growth rate is much lower and seems to be stable during the summer and autumn. Beacham (1980) in turn demonstrated that individuals of Microtus townsendii under $40 \mathrm{~g}$ had the same growth rates in 3 populational phases. As a result of this body size is an effect of various asymptotic body weights.

\section{Conclusions}

The Finse root vole population showed distinct $3-4$ year density cycles where the magnitude of peaks differed greatly (Fig. 2). Peaks are usually reached in the autumn, and the population crashed during the winter. The increase phase may last for a year with its density peak reached in next calendar year.

Sexual dimorphism manifested itself distinctly in mature individuals. Males showed greater body and skull dimensions as a result of their better survival.

Vole body size increased from the increase phase to peak density (Chitty Effect) and the higher the peak, the larger is the body size and higher percentage frequencies of overwintering individuals (Table 8 ).

Acknowledgements: Nils C. Stenseth and Rolf A. Ims are thanked for commenting on an earlier draft of this manuscript. We are also indebted to Tom Warren for correcting English.

\section{References}

Anderson P. K. 1970. Ecological structure and gene flow in small mammals. Symp. zool. Soc. Lond. 26: $299-325$.

Bauer K. 1953. Zur Kenntnis von Microtus oeconomus mehelyi Ehik. Zool. Jb. 82, 1/2: 70 - 94 . 
Bashenina N. V. 1977. Puti adaptacii myshevidnych gryzunov. Nauka. Moskva: 1- 352.

Beacham T. D. 1979. Survival in fluctuating populations of the vole, Microtus townsendii. Can. J. Zool. 57: $2375-2384$.

Beacham T. D. 1980. Demography of declining populations of the vole, Microtus townsendii. J. Anim. Ecol. 49: $453-464$.

Boonstra R. and Boag P. T. 1987. A test of the Chitty hypothesis: inheritance of life-history traits in meadow voles Microtus pensylvanicus. Evol. 41: 929 - 947.

Bondrup-Nielsen S. and Ims R. A. 1990. Reversed sexual dimorphism in microtines: are females larger than males or are males smaller than females? Evol. Biol. 4: 261 - 272.

Brown E. B. III. 1973. Changes in patterns of seasonal growth of Microtus pennsylvanicus. Ecology 54: $1103-1110$.

Chitty D. 1952. Mortality among voles (Microtus agrestis) at Lake Vyrnwy, Montgomeryshire in 1936 - 39. Phil. Trans. R. Soc., ser. B. 236: $505-552$.

Chitty D. 1958. Self regulation of numbers through changes in variability. Cold Spring Harb. Symp. Quant. Biol. 22: 277 - 280 .

Chitty D. 1967. The natural selection of self-regulatory behaviour in animal populations. Proc. of the Ecol. Society of Australia 2: $51-78$.

Chitty H. and Chitty D. 1962. Body weight in relation to population phase in Microtus agrestis. Symp. Theriologicum, Brno, 1960: 77 - 86.

Dehnel A. 1946. Przyczynek do znajomosci przedstawicieli Microtus Schrank z Polesia i Wileńszczyzny. Fragm. Faun. Muz. Zool. Pol. 5: 1-24.

Ehik G. 1953. The occurrence of the root vole (Microtus oeconomus (Pall.)) at the Kisbalaton. Ann. Hist.- Natur. Mus. Nat. s. nova, 3: $521-526$.

Gaines M. S. 1985. Genetics. [In: Biology of New World Microtus. R. H. Tamarin, ed.]. Amer. Soc. Mammal., Stillwater. OK.

Gębczyńska Z. 1964. Morphological changes occurring in laboratory Microtus agrestis with age. Acta theriol. 9: $67-79$.

Gębczyńska Z. 1967. Morphological variability of Lagurus lagurus (Pallas, 1773) in laboratory conditions. Acta theriol. 12: $535-543$.

Gourley R. S. and Jannett F. J. 1975. Pine and montane vole age estimates from eye lens weight. J. Wildl. Manage. 39: $550-556$.

Hagen A., Kjelvik S., Liestöl K., Østbye E., Skar H-J. and Swartzman G. 1975. Reports from the High Mountain Ecology Research Station, Finse, Norway. A simple ecosystem-model with emphasis on small rodents. University of Oslo: $1-104$.

Hagen A., Stenseth N. C., Østbye E. and Skar H.-J. 1980. The eye lens as an age indicator in the root vole. Acta theriol. 25: $39-50$.

Iverson S. L. and Turner B. N. 1974. Winter weight dynamics in Microtus pennsylvanicus. Ecology 55: $1030-1041$.

Kanep S. V. 1967. Opyt biometricheskogo issledovanya priznakov cherepa nekotorych blizkich vidov serykh polevok fauny SSSR. Acta theriol. 12: $111-134$.

Karaseeva E. V. Narskaja E. V. and Bernstein A. D. 1957. Polevka-ekonomka, obitayushchaya v okrestnostakh ozera Nero Jaroslavskoy oblasti. Biull. MOIP, 62: 5 - 18.

Kratochvil J. and Rosicky B. 1955. Hraboš severni (Microtus oeconomus), relikt zvireny z dobovy lodove v CSR. Prace Brnenske Zaklady CAV. 27: $33-72$.

Krebs C. J. 1964. Cyclic variation in skull-body regression of lemmings. Can. J. Zool. 42: 631 - 643.

Krebs C. J. 1966. Demographic changes in fluctuating populations of Microtus californicus. Ecol. Monogr. 36: 273 - 273.

Krebs C. J. 1978. A review of the Chitty hypothesis of population regulation. Can. J. Zool. 56: $2463-2480$.

Krebs C. J. and Myers J. H. 1974. Population cycles in small mammals. Adv. Ecol. Res. 8: 267 - 399. 
Krebs C. J. Keller B. L. and Tamarin R. H. 1969. Microtus population biology: demographic changes in fluctuating populations of $M$. ochrogaster and $M$. pennsylvanicus in southern Indiana. Ecology 50: $587-607$.

Krebs C. J., Gaines M. S., Keller B. L., Myers J. H. and Tamarin R. H. 1973. Population cycles in small rodents. Science 179: $35-41$.

Krebs C. J., Wingate J., Ledne J., Redfield J. A., Taitt M. and Hillborn R. 1976. Microtus population biology: dispersal in fluctuating populations of $M$. townsendii. Can. J. Zool. 54: 79 - 95 .

Lidicker W. Z., Jr. 1988. Solving the enigma of microtine cycles. J. Mammal. 69: 225 - 235.

Markowski J. 1980. Morphometric variability in a population of the root vole. Acta theriol. 25: $155-200$.

Mayr E. 1963. Populations, species and evolution. The Belknap Press, Harvard Univ. Press, Cambridge: $1-779$.

Mezherin V. A. 1964. Javlenie Denela i jego vozmozhnoye obiasnienie. Acta Theriol. 8: 95 - 114.

Morris P. 1972. A review of mammalian age determination methods. Mamm. Rev. 2: $69-104$.

Ognev S. I. 1950. Zveri SSSR i prilezhajschikh stron. vol. 7. Gryzuny Izd. Akad. Nauk SSSR, Moskva-Leningrad: 1 - 706.

Østbye E., Berg A., Blehr O., Espeland M., Gaare E., Hagen A., Hesjedal O., Hagvar S., Kjelvik S., Lien L., Mysterud I., Sandhaug A., Skar H.-J., Skartveit A., Skre O., Skogland T., Sollhoy T., Stenseth N. C. and Wielogolaski F. E. 1975. Hardan-gervidda, Norway. [In: Structure and function of tundra ecosystems. T. Rosswall and W. O. Heal, eds]. Ecol. Bull. Stokholm, 20: $225-264$.

Pantaleyev P. A. and Terechina A. N. 1976. Issledovanya vnutripopulyacyonnoy izmenchivosti na primere vodyanoy polevki. Fauna i ekologija gryzunov. 13: $99-163$.

Pjastolova O. A. 1971. Polevka-ekonomka. AN Nauk SSSR, Ural. Fil. Trud. Inst. Ekol. 80: 127 - 149.

Pucek Z. 1963. Seasonal changes in brain-case of some representatives of the genus Sorex from the Palearctic. J. Mammal. 44: 523 - 536.

Ruprecht A. L. 1974. Craniometric variations in central European populations of Ondatra zibethica (Linnaeus, 1776). Acta theriol. 19: $436-507$.

Saint- Girons M.-C. and Mazàk V. 1971. Donnees morphologique sur queleques micromammiferes en Laponie. Z. Säugetierk. 36: $179-190$.

Schwarz S. S. 1962. Morfologicheskiye i ekologicheskiye osobiennosti zemloroyek na kraynem severnom predele ich rasprastranienya. Tr. In-ta Biol. Ural. Fil. AN SSSR. 29: 45 - 51.

Schwarz S. S. 1969. Evoluconnaya ekologiya zhivotnykh. AN SSSR Ural. Fil. Sverdlovsk: 1 - 198.

Schwarz S. S., Pokrovskij A. N., Istchenko V. G., Oljenev V. G., Ovtschinnikova N. A. and Pjastolova O. A. 1964. Biological peculiarites of seasonal generations of rodents with special references to the problem of senescence in mammals. Acta theriol. 8: 11-41.

Schwarz S. S., Bolshakov V. N., Olenjev V. G., Ovtschinnikova N. A. and Pjastolova O. A. 1969/70. Population dynamics of rodents from northern and mountain geographical zones. [In: Small mammals populations. K. Petrusewicz and L. Ryszkowski, eds]. PWN, Warszawa: $187-201$.

Snigirevskaja E.M. 1961. Nabludenja nad polevkoj-ekonomkoj na ostrovach sredniej Volgi. Tr. Zool. In-ta. AN SSSR. 29: $137-155$.

Sokal R. R. and Rohlf J. F. 1984. Biometry. W. H. Freeman and Company, San Francisco: 1-859.

Stenseth N. C. 1978. Demographic strategies in fluctuating populations of small rodents. Oecologia 33: $149-172$.

Taitt M. J. and Krebs C. J. 1985. Population dynamics and cycles. [In: Biology of New World Microtus. R. H. Tamarin ed.]. Spec. Publ. Amer. Soc. Mamm. 8: 567 - 620.

Tast J. 1972. Annual variations in the weight of root voles, Microtus oeconomus, in Finish Lapland. Aquilo (ser. zool.) 15: $25-32$.

Tast J. 1976. Winter breeding of the root vole, Microtus oeconomus, in 1972/73 at Kilpisjärvi, Finish Lapland. Ann. Zool. Fenn. 13: $174-178$. 
Tast J. 1982. Microtus oeconomus (Pallas, 1776) - Nordische Wühlmaus, Sumpfmaus. [In: Handbuch der Säugetiere Europas. J. Niethammer and F. Krapp, eds]. Bd 2/1. Rodentia: $374-396$.

Wasilewski W. 1956. Untersuchungen über die Veränderlichkeit des Microtus oeconomus Pall. in Białowieża - Nationalpark. Annls. Univ. M. Curie-Skłodowska C. 9: $355-386$.

Zimmermann K. 1942. Zur Kenntnis von Microtus oeconomus (Pallas). Arch. f. Naturgesch. Leipzig. 11: $174-197$.

Zimmermann K. 1955. Körpergröße und Bestandsichte bei Feldmaus (Microtus arvalis). Z. Säugetierk. 20: $114-118$.

Yablokov A. V. 1966 (Orig. in Russian) 1974. Variability of Mammals (Izmenchivost' Mlekopitayushchikh). Revised ed. Amerind Publ. Co. Pvt. Ltd., New Delhi: XV +1-350.

Received 26 February 1992, accepted 29 June 1992. 